両極性パルスによる焼結ダイヤモンドの放電加工*

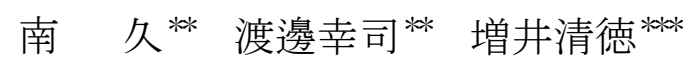

\title{
Electrical Discharge Machining for Sintered Polycrystalline Diamond using Bipolar Pulse Generator
}

\author{
Hisashi MINAMI, Koji WATANABE and Kiyonori MASUI
}

\begin{abstract}
Sintered polycrystalline diamond (PCD) is widely employed for cutting tools because of its excellent hardness and high wear resistance. However, it is extremely difficult to shape PCD tools by conventional machining methods. We describe the truing of a PCD tool by electrical discharge machining (EDM). Although EDMing of PCD is possible under PCD positive polarity, the removal rate is relatively low. In this paper, we discuss the possibility of applying a bipolar pulse for the EDMing of PCD. It is confirmed that the removal rate of PCD using a bipolar pulse is higher than that using a normal pulse (electrode positive or negative polarity). Moreover, the electrode wear ratio is also improved.
\end{abstract}

Key words: EDM, polycrystalline diamond (PCD), bipolar pulse

\section{1. 緒言}

焼結ダイヤモンド(sintered Polycrystalline Diamond：PCD)は，極めて高い硬度と優れた耐 摩耗性を有することから, 切削工具や様々な耐摩 耗性部品に利用されている。しかし，その優れた 機械的特性によって, PCD を高精度に加工するこ とは難しい.

PCD は焼結助剤としてコバルトやニッケルな どの金属を含有し, 通電性を持つことから放電加 工が可能 1) 2) であるが，ダイヤモンド粒子自体に 導電性がないため, 加工精度や加工能率の点で課 題がある。これに対して, 導電性がある特殊なダ イヤモンドで PCD を製作し，これを工具に適用

\footnotetext{
* 第 206 回電気加工研究会にて発表

** 地方独立行政法人 大阪産業技術研究所(和泉市あゆ

み野 2-7-1)

*** E.D.M.ラボ（富田林市中野町 1-221-1）
}

しようとする試み 3) や, 一般の PCD に対しては, 超音波振動を付与した放電加工 ${ }^{4)}$, ダイヤモンド の熱化学的反応を利用した放電加工 5) 6) など，加 工速度の向上を目的とした試みがなされている。

著者らは, 絶縁性セラミックスの放電加工 7)で 行われているように, 放電加工中に加工油から生 成される熱分解カーボンを導電性皮膜として PCD 上に形成させながら加工することで, 非導電 体であるダイヤモンド粒子自体を直接加工する ことができ, 比較的高精度な放電加工が行えるこ とを報告した ${ }^{8)}$. しかしながら, PCD を陽極とし た正極性加工では，加工面に形成される熱分解力 一ボンが保護皮膜として作用し9), PCD の加工能 率を低下させる原因にもなる。このため, PCD 上 に形成する熱分解カーボンを必要最小限にして 加工することが, PCD の加工能率を向上させるた めに重要である.

一方, PCD を陰極とした逆極性加工では, 非導 
電体のダイヤモンド粒子を直接加工することは できないため, 比較的大きなダイヤモンド粒子で 構成される PCD では, 除去加工は進行しない. これは，逆極性パルスによる放電加工では，熱分 解カーボンは陰極である PCD 上に形成しないた め, コバルトなどの金属部が除去されると PCD の表面に通電性がなくなり放電が発生しなくな るためである.このため, 正極性パルスによる放 電加工で, PCD 上に形成された熱分解カーボン は，電極極性を反転することで除去される，そこ で, 電極極性を定期的に反転させる両極性パルス 10) 13）を用いるとともに，それぞれの極性パルス を最適化することで, PCD 上への熱分解カーボ ンの形成を必要最小限に抑制しながら， PCDの 放電加工を効率的に行えると考えられる.

本研究では, PCD の放電加工速度の向上を目的 として, 電極極性を定期的に反転させる両極性パ ルスによる PCD の放電加工について検討した.

\section{2. 実験方法}

Fig.1 に本実験で用いた両極性パルス回路の概 略図を示す. 形彫り放電加工機の電源回路にトラ ンジスタによるスイッチング $(\mathrm{Ps})$ によって電極 極性を反転させる装置（HSPC：High Speed Polarity Changer) を付加した. Ps の接点が A 側では逆極性（工具電極：十），B 側では正極性

（工具電極：-）に接続される。また，スイッチ ングトランジスタ TsA, TsBによって, 正・逆極 性パルスの放電持続時間, 休止時間, ピーク電流 值をそれぞれ個別に設定することができる．Ps は電源回路のスイッチングトランジスタ TsA, TsB の発振器と同期し, それぞれの極性のパルス 数を 1 255 の範囲で任意に設定することができ る. Fig.2 に正極性パルス $(t e=5 \mu \mathrm{s})$ が 20 パル ス, 逆極性パルス $(t e=30 \mu \mathrm{s})$ が 2 パルス毎にそ れぞれの極性パルスを切り替えて加工した場合 の電圧電流波形を示す。また, Table 1 に実験条 件を示寸.

\section{3. 実験結果および考察}

Fig.3 は，PCD をそれぞれの極性（単極性）で 加工した場合の放電持続時間と加工速度の関係 を示す.また, 代表的な加工面 (SEM 像)を Fig.4

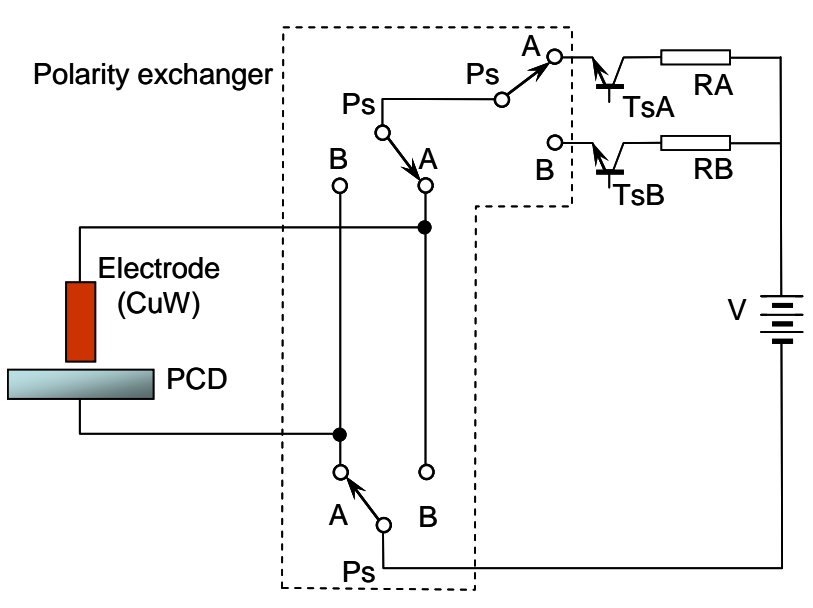

Fig.1 Circuit diagram of Bipolar pulse generator

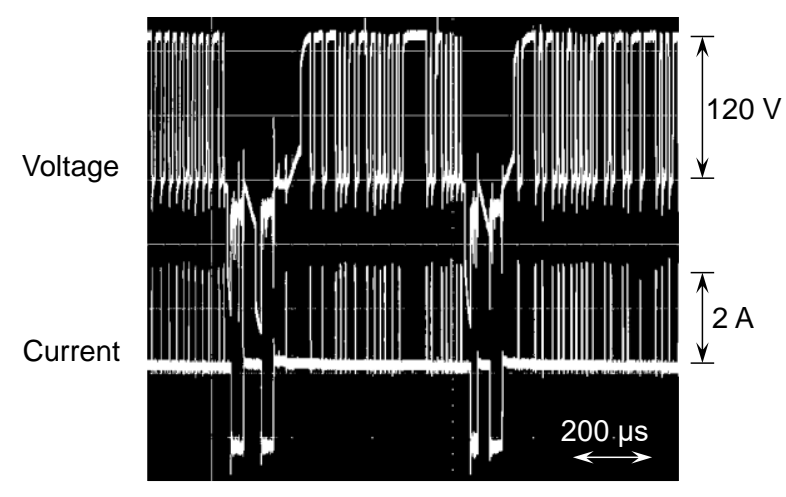

Fig.2 Bipolar pulse wave form (20:2 pulses)

Table 1 Experimental conditions

\begin{tabular}{c|l}
\hline EDM machine & Sodick AP1L \\
\hline Tool electrode & CuW alloy : $\phi 3 \mathrm{~mm}$ \\
\hline Discharge current & $i_{e}: 2 \mathrm{~A}$ \\
\hline Discharge duration & $t_{e}: 1 \sim 120 \mu \mathrm{s}$ \\
\hline Open circuit voltage & $u_{e}: 120 \mathrm{~V}$ \\
\hline Duty factor & $\tau: 10 \%$ \\
\hline EDMed time & 90 min. \\
\hline Workpiece & $\begin{array}{l}\text { Diamond grain size }: 25 \mu \mathrm{m} \\
\text { Binder metal : Cobalt } \\
(\text { CCD })\end{array}$ \\
\hline Porarity $: 18 \mathrm{wt} \%)$
\end{tabular}

に示す. PCD を(-) とした逆極性加工では, 放 電持続時間によらず加工速度はほぼ一定值を示 す。また, 得られた加工面には, 部分的に深い加 工痕が観察されるが，導電性のないダイヤモンド 


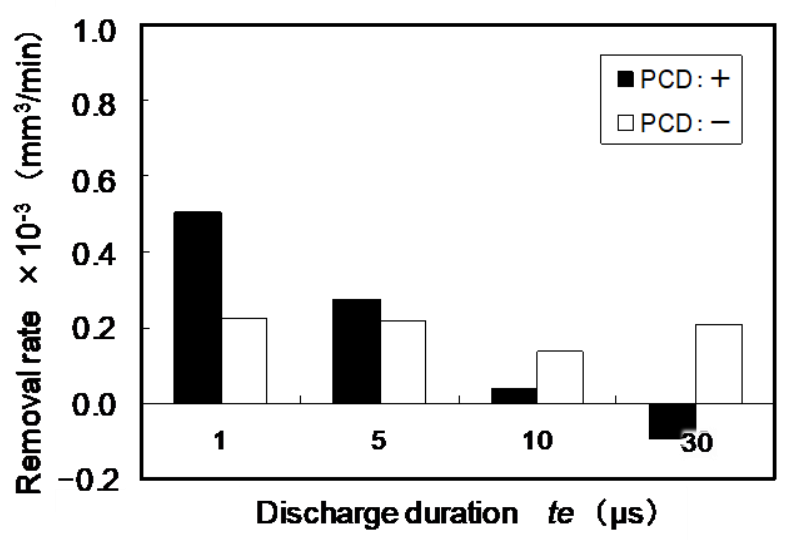

Fig.3 Electrode polarity and Removal rate

粒子は加工されずに残っている. 一方, $\mathrm{PCD}$ を （+）とした正極性加工では，比較的平滑な加工面 が形成されており, ダイヤモンド粒子は直接放電 加工されていると考えられる。この時, SEM 像 で加工面全体が白っぽく観察されるのは, 熱分解 カーボン以外に比較的原子量が大きな 元素が加工面に存在するためであると 推察される.また，この極性では，放電 持続時間（te）が長いほど加工速度は低 下し，特に $t e=30 \mu \mathrm{s}$ 以上では，加工 速度は負の值を示寸.

Fig.5 は, $t e=30 \mu \mathrm{s}$ の正極性加工で 得られた加工面の断面曲線を示す. 放電 加工面は, 前加工面（研磨面）に比べて 全体的に盛り上がっており, 除去加工さ れた形跡は認められない。この加工面 （付着物）を EDX で分析した結果，

Fig.6 に示すように加工面からは, PCD の構成素材を示寸 $\mathrm{C}, \mathrm{Co}$ 以外に $\mathrm{Cu}, \mathrm{W}$ が検出された. $\mathrm{Cu}, \mathrm{W}$ は, 工具電極材 料 $(\mathrm{CuW}$ 合金) であることから，放電 加工時に電極材料が加工面へ転写され たと考えられる。また，Cに関しては， PCD を構成するダイヤモンドを検出し たもの以外に加工油から生成された熱 分解カーボンが付着物に含まれている ことを示すと考えられる.しかし，両者 を区別することができないため，ここで は， $\mathrm{Cu}, \mathrm{W}$ に注目し，EDXによる定量

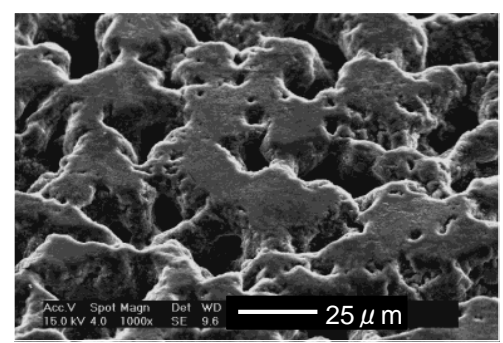

(a) PCD : (-)

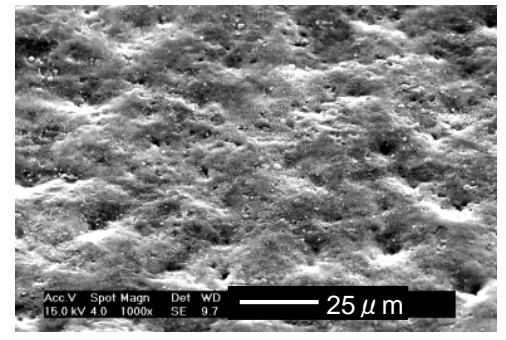

(b) PCD : (+)

Fig.4 EDMed surface of PCD $(t e=5 \mu \mathrm{s})$

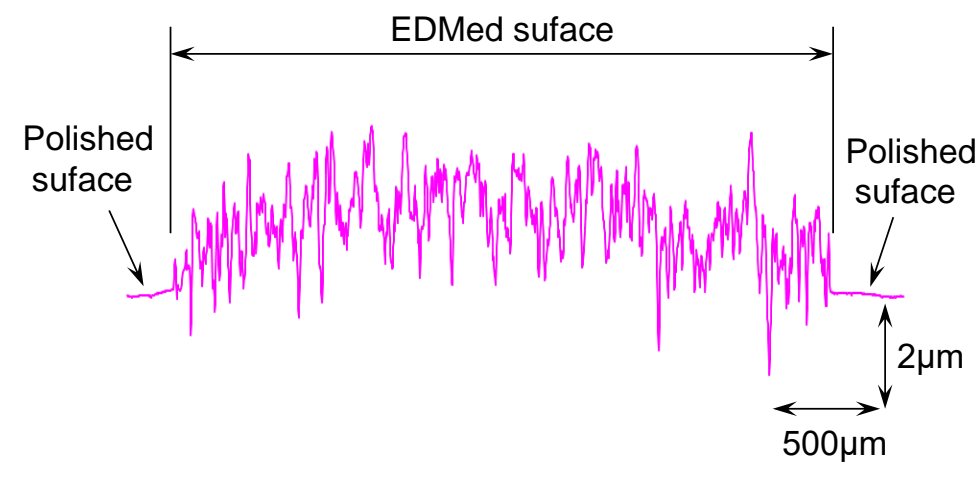

Fig.5 Shape of cross section $(t e=30 \mu \mathrm{s}, \quad \mathrm{PCD}:(+))$

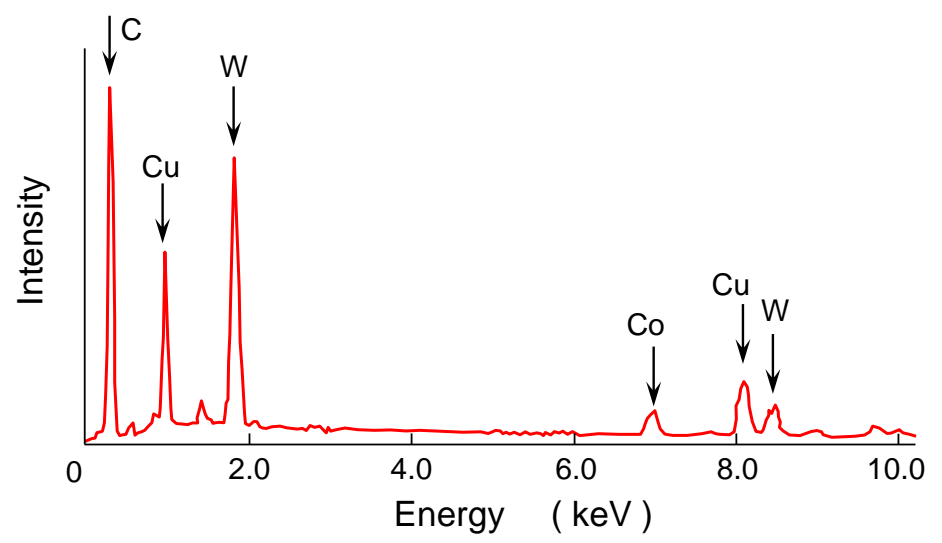

Fig.6 EDX spectrum of EDMed surface (PCD: (+)) 
分析結果から，放電持続時間と $\mathrm{Cu}, \mathrm{W}$ の含有率 の関係について調べた。

Fig.7 に, 加工面から検出される $\mathrm{Cu}$ と W の含有 率の和と放電持続時間との関係を示す. PCD を （-）とした逆極性加工では，電極材料 $(\mathrm{Cu}+\mathrm{W})$ の 含有率は低い值を示すのに対して，PCD を(+) とした正極性加工では, 電極材料の含有率は比較 的高く, 放電持続時間が長いほど増加する. 従来 より，放電持続時間を長く設定して加工した場合， 加工油から生成される熱分解カーボンが陽極面 に付着し，保護皮膜として作用する 9) ことが知ら れている. PCD の場合, 加工面には, 熱分解力一 ボン以外にも相手電極材料が転写され, その付着 量は放電持続時間が長いほど増加する.このこと から，PCD を(+) とする正極性加工において, 放電持続時間が長いほど加工速度が低下するの は, 熱分解カーボンに加えて, 工具電極材料が加 工面へ転写される量が増加したことによると考 えられる。

このような熱分解カーボンや電極材料の加工 面への付着は, 非導電体であるダイヤモンド表面 に通電性を与え，放電加工を可能にする一方で,

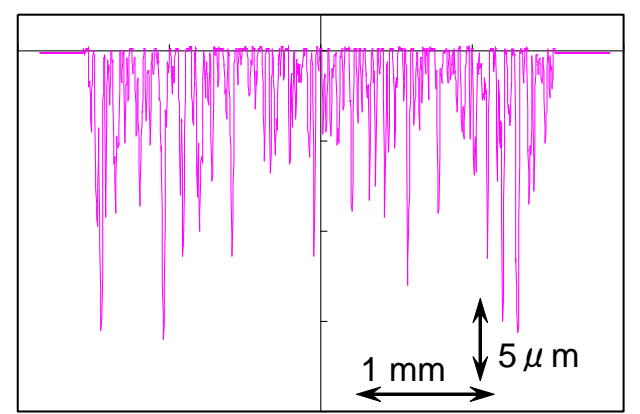

(a) PCD : (-)
加工速度を低下させる原因にもなる。このため, PCD の加工速度を向上させるためには, 加工面に 付着するこれらの量を必要最小限にして加工す る必要がある。そこで，ダイヤモンド粒子を直接 加工することができる正極性 (PCD : (+)) パルス と加工面に形成された熱分解カーボンや電極材 料を除去することができる逆極性 (PCD : (-)) パ ルスを適当なタイミングで反転させる両極性パ ルスによる放電加工について検討した. 本研究で は, 加工面に形成される熱分解カーボンや工具

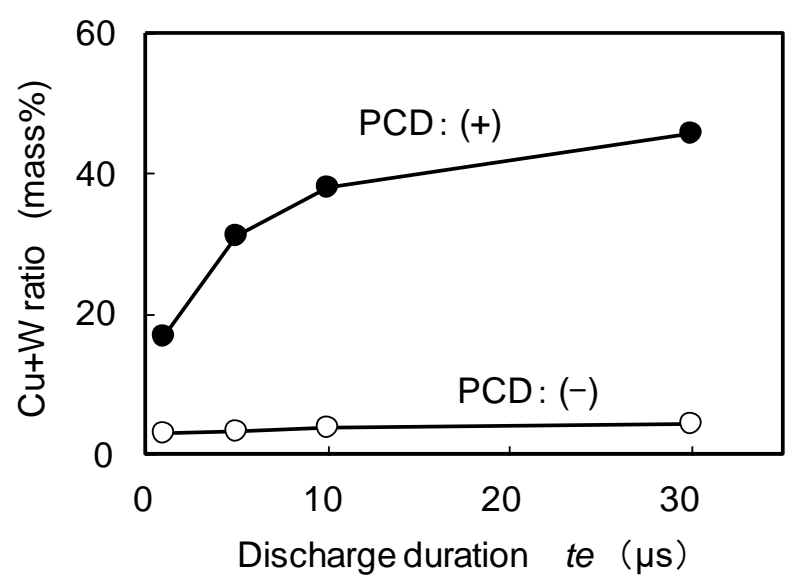

Fig.7 $\mathrm{Cu}+\mathrm{W}$ ratio on EDMed surface

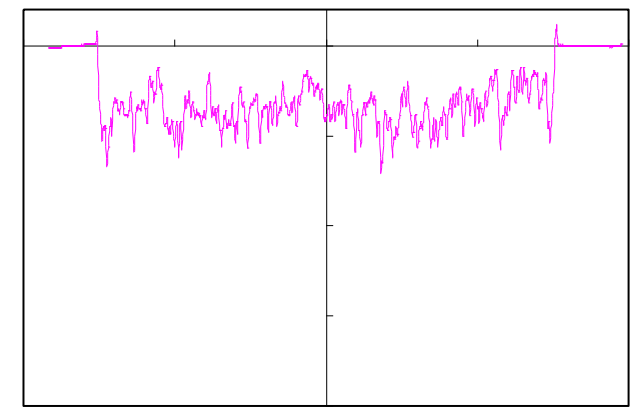

(b) PCD : (+)

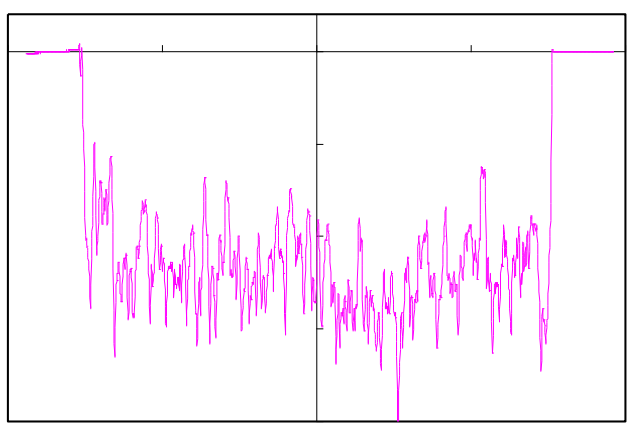

(c) $\operatorname{PCD}(+):(-)=150: 150$

Fig.8 Shape of cross section 
電極材料の転写量が加工面全体で均一化され， 極性を切り替えるごとにそれらが大きく変動 しないように比較的短いタイミングで極性を 反転するようにした。

Fig.8は，PCDを(+)，または (-) とする単極 性パルスで加工した場合, および電極極性を定期 的に反転させる両極性パルスで加工した場合の 加工面の断面曲線を示寸. なお, 極性を反転させ るタイミング (連続して与えるパルス数) は, 25,

150，250 パルス毎として行ったが，これらに大 きな違いは認められなかった 14)ため,ここでは 150 パルス毎に極性を反転させた結果を示す.

PCD を(-) とした単極性加工では, 加工面は ところどころ深く加工されてはいるものの, ダイ ヤモンド粒子であると考えられる部分は，加工さ れずに残っており, 全体的に除去加工は進行して いない，一方，PCD を（+）とした単極性加工で は, 全体的に加工は進んではいるものの, 除去量は比較的少ない。これに対して, 両極性パルスで加工した場合, 単極性加 工に比べて，深く加工されている．この ことから，極性を反転させる両極性パル スが PCD の加工速度を向上させるのに 有効であるといえる。また，両極性パル スによる加工においても, 全体的に除去 加工が進んでいることから, ダイヤモン ド粒子が直接放電加工されていると考え られる. なお, 加工面粗さについては, PCD を（+）とした単極性加工では 4.8 $\mu \mathrm{mRz}, \mathrm{PCD}$ を (-) とした単極性加工で は $14.5 \mu \mathrm{mRz}$ であるのに対して, 両極 性加工では $10.0 \mathrm{\mu mRz}$ と両者の中間的 な值を示し，両極性パルスによる効果は 認められなかった. このことから, 加工 面粗さが優先される仕上げ加工において は, PCDを（+）とする単極性加工が有効 であるといえる。

Fig.9 は, Fig.8 の加工面を EDX で分 析した結果を示す. PCD を(+) とする単 極性加工で得られた加工面において, 電 極材料 $(\mathrm{Cu}, \mathrm{W})$ の含有率が比較的高い值
を示すのに対して，両極性パルスによる加工面で は，これらの含有率は減少している。これは，正 極性 (PCD：(+)) パルスによる加工時に加工面に 転写された電極材料が逆極性 (PCD : $(-))$ パルス を付与することで適度に除去されたためと考え られる。また, 熱分解カーボンの形成・除去につ いてもそれぞれの極性パルスで同様の効果があ ったと推察されることから，それぞれの極性パル スを定期的に切り替えて与えることによって， PCD の加工面に形成される熱分解カーボンや工 具電極材料の転写を適度に制御することができ, このことによって, PCD の加工速度を改善するこ とができたといえる.

次にそれぞれの極性パルスをどのような比率 で反転させれば効果的であるかについて調べた。

Fig.10 は，両極性パルスにおいて正・逆極性パル スの比率を変えて PCD を加工した場合の加工速

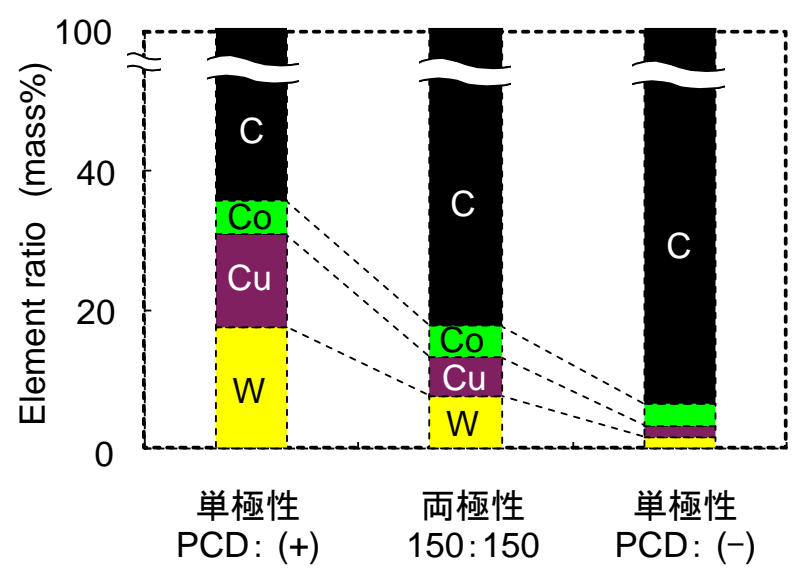

Fig. 9 Element ratio on EDMed surface

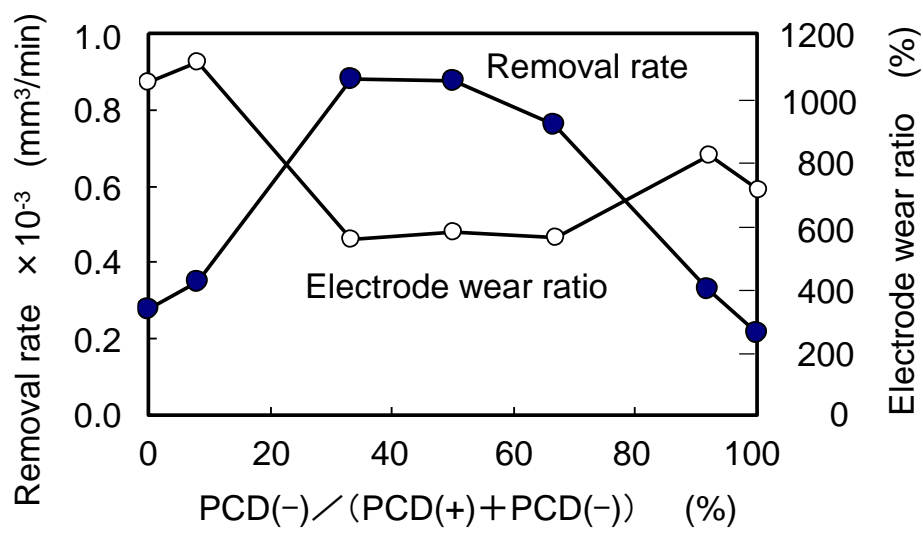

Fig. 10 Removal rate and Electrode wear ratio 
度, 電極消耗率を示寸. 図の横軸は, 正・ 逆極性パルスの比率（パルス比）で，極 性を反転するまでに与える正極性 (PCD：(+)) パルス数と逆極性 (PCD : (-)) パルス数の和に対する逆極性パルス 数の割合とした。パルス比が $0 \%$ とは, 正極性パルスのみの単極性加工， $100 \%$ とは，逆極性パルスのみの単極性加工を 示す. PCD を両極性パルスで加工した場 合，いずれのパルス比においても，それ ぞれ単極性で加工した場合に比べて, 加 工速度, 電極消耗率ともに向上している. また, パルス比が 30〜 70\%の範囲で比較 的良好な結果が得られている.

次に両極性におけるそれぞれの極性パルスに ついて, 放電持続時間の最適值を調査した.まず, PCD を（+）とする正極性パルスについては,

Fig.3 に示寸単極性加工での結果から, 比較的高 い加工速度が得られる放電持続時間 $t e=1 \mu \mathrm{s}$ を選択した。また，PCD を（-) とする逆極性パ ルスについては，単極性では PCD を加工するこ とができないことから, 正極性パルスを $t e=1 \mu \mathrm{s}$ に固定した両極性パルスを用いて, 逆極性パルス の放電持続時間の影響について調べた。この時, 連続して与える正・逆極性パルスのパルス数 （n）については，それぞれの極性で放電時間の 合計 $(t e \times n)$ が等しくなるように次式から決定 した.

$$
t e(+) \times n(+)=t e(-) \times n(-) \quad \cdots(1)
$$

Fig.11 は，PCD を両極性パルスで加工した場 合の逆極性パルスの放電持続時間と加工速度, 電 極消耗率の関係を示す. 放電持続時間が長いほど, 加工速度は向上し, 電極消耗率は改善する傾向を 示す.一般に工具電極を (+) とする逆極性加工で は, 放電持続時間が長くなると工具電極面に形成 される熱分解カーボンの量が増加し, 電極消耗率 が改善されることが知られている. 両極性パルス による PCD の放電加工においても, 逆極性パル スの放電持続時間を長くした場合には同様の効 果で電極消耗率が改善されたと考えられる.

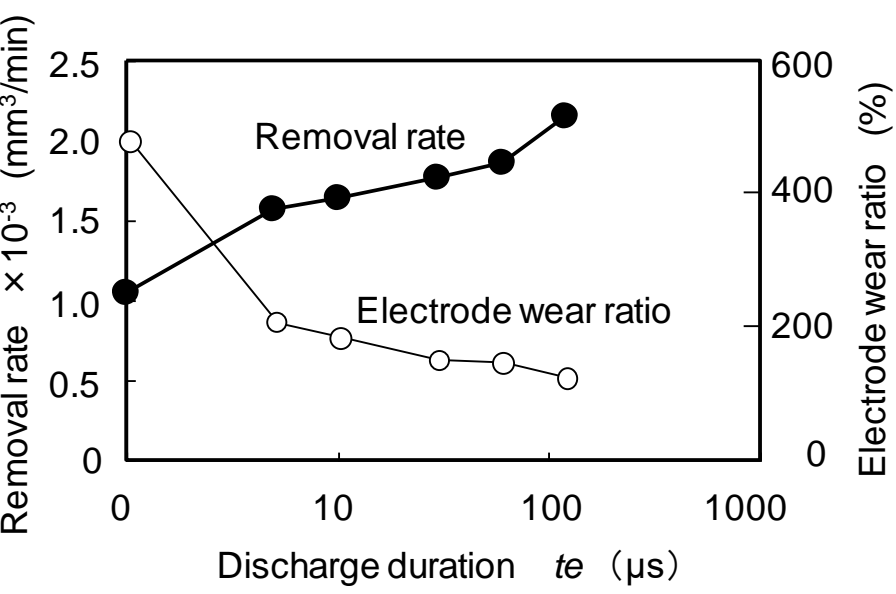

Fig.11 Removal rate and Electrode wear ratio

以上のことから，両極性パルスによる PCD の 放電加工では，正極性パルスの放電持続時間を短 く, 逆極性パルスの放電持続時間を長く設定した 方が, 加工速度, 電極消耗率ともに良好な結果が 得られることがわかった。

\section{4. 結言}

$\mathrm{PCD}$ の放電加工速度の向上を目的として, 電極 極性を定期的に反転させる両極性パルスによる 放電加工について検討した結果，次のことがわか った.

（1） PCD を陽極とした単極性加工では，加工油か ら生成される熱分解カーボンに加えて, 相手電 極材料が加工面に転写され，これが PCD の加 工速度を低下させる.

（2）両極性パルスを適用し，正極性パルスで加工 面に形成された熱分解カーボンや電極材料を逆 極性パルスによって適度に除去することで,

PCD の加工速度, 電極消耗率を改善することが できる.

（3）正，逆極性パルスの比率を 30〜 70\%とした場 合に加工速度, 電極消耗率の改善効果が高い.

（4）正逆それぞれの極性パルスの放電持続時間は, 正極性パルスについては短く, 逆極性パルスに ついては長く設定した方が, 加工速度, 電極消 耗率ともに良好な結果が得られる。

\section{謝 辞}

本研究は, 文部科学省科学研究費補助金(基盤研 
究(c):21560139)の助成のもとで行われました.ま た，実験においては，(株)ソディックにご協力い ただきました。関係各位に感謝申し上げます。

\section{参 考文 献}

1) G.Spur, M.Puttrus and U.W.Wunsch:Wire EDM of PCD, Industrial Diamond Review, Vol. 48, No. 529 (1988) pp.264-266.

2) 中奥 洋, 増沢隆久, 藤野正俊 : 焼結ダイヤモ ンドの微細放電加工, 電気加工学会誌, Vol.39,

No.91 (2005) pp.24-28.

3）鈴木 清, 二八宮進一, 岩井 学: 導電性ダイヤ モンドを原料とする PCD（EC-PCD）の放電加 工, 電気加工学会全国大会講演論文集, (2009) pp.57-64.

4) 高田拓哉, 周 志容, 岡道拓也, 二八宮進一, 岩井 学, 鈴木 清 : PCD の放電加工における超 音波振動付与の影響, 電気加工学会誌, 精密工 学会春季大会学術講演会講演論文集, (2012) pp.111-112.

5) J.Yan, K.Watanabe and T.Aoyama : Micro-electrical discharge machining of polycrystalline diamond using rotary cupronickel electrode, CIRP Annals Manufacturing Technology, Vol.63, No.1 (2014) pp.209-212.

6) 岩井 学, 橋本英明, 川崎智将, 鈴木 清 : 特定 遷移金属電極による PCD の高能率放電加工, 精密工学会春季大会学術講演会講演論文集, (2015) pp.79-80.

7）福澤 康, 谷 貴幸, 岩根英二, 毛利尚武 : 放電
加工機を用いた絶縁性材料の加工, 電気加工学 会誌, Vol.29, No.60 (1995) pp.11-21.

8）南 久, 渡邊幸司, 増井清徳, 鍋倉伸嘉 : 放電 加工による焼結ダイヤモンド工具の成形加工, 電気加工学会誌, Vol.44, No.105 (2010) pp.17-24.

9）鈴木政幸, 毛利尚武, 齋藤長男, 武沢英樹 : 放 電加工における電極低消耗の研究(第 1 報)-放電 除去現象の観察-, 電気加工学会誌, Vol.26, No.52 (1992) pp.47-56.

10）増井清徳，佐藤幸弘，曾根 匠，中山実，金 子雄二 : 放電加工における異常アーク面の解析 とその改善一両極性パルスによる異常アークの 回避一, 電気加工学会全国大会(1994)講演論文 集, pp.15-18.

11）夏 亘，国枝正典：極性反転パルスによる放 電加工特性の向上, 日本機械学会論文集 ( $\mathrm{C}$ 編), Vol.61, No.58 (1995) p.281-286.

12）宇野義幸, 岡田 晃, 伊藤 満, 高木 俊: 高速 極性切替放電加工に関寸る研究, 電気加工学会 誌, Vol.29, No.60 (1995) pp.22-30.

13）河谷浩司, 花岡大生, 福澤 康 : 極性反転回路 を用いた絶縁性 $\mathrm{Si}_{3} \mathrm{~N}_{4}$ セラミックスの微細放電 加工, 2010 年度精密工学会春季大会学術講演会 講演論文集，（2010）pp.563-564.

14）南 久, 渡邊幸司, 増井清徳 : 両極性パルス による焼結ダイヤモンドの放電加工特性，2011 年度精密工学会秋季大会学術講演会講演論文集, (2011) pp.721-722.

(2019年8月23日受付) 